\title{
HUBUNGAN ANTARA DUKUNGAN SOSIAL DAN HOMESICKNESS PADA MAHASISWA RANTAU YANG BERASAL DARI LUAR PULAU JAWA DI UNIVERSITAS KATOLIK WIDYA MANDALA SURABAYA KAMPUS PAKUWON CITY
}

\author{
Trinanda Linggayuni Istanto ${ }^{1}$
}

Agustina Engry ${ }^{2}$

Fakultas Psikologi Universitas Katolik Widya Mandala Surabaya

\begin{abstract}
ABSTRAKSI
Homesickness merupakan distress yang dialami seseorang karena adanya perpisahan dari tempat tinggalnya ke lingkungan yang baru. Homesickness dapat berdampak negatif bagi individu sehingga dibutuhkan pemberian dukungan sosial. Dukungan sosial merupakan perasaan nyaman yang terjadi melalui proses sosial yang membuat individu dapat mengurangi dampak negatif yang disebabkan oleh stress yang negatif. Penelitian ini bertujuan untuk menguji hubungan antara dukungan sosial dan homesickness pada mahasiswa rantau semester satu yang berasal dari luar Pulau Jawa di Unika Widya Mandala Surabaya Kampus Pakuwon City. Subjek dalam penelitian ini $(\mathrm{N}=149)$ adalah mahasiswa semester satu yang berasal dari luar Pulau Jawa. Pengambilan sampel dilakukan dengan teknik disproportionate stratified random sampling. Penelitian ini diuji menggunakan teknik korelasi non-parametrik Kendall's Tau- $b$. Hasil penelitian menunjukkan koefisien korelasi $(\mathrm{r})$ sebesar $=-0,381$ dan $p=0,000(p<0,05)$ yang berarti ada hubungan antara dukungan sosial dan homesickness pada mahasiswa rantau semester satu yang berasal dari luar Pulau Jawa di Universitas Katolik Widya Mandala Surabaya Kampus Pakuwon City.
\end{abstract}

Kata Kunci: Homesickness, Dukungan Sosial, Mahasiswa Tahun Pertama

\section{ABSTRACT}

Homesickness is a distress caused by separation from home to the new environment. Homesickness often occurs to overseas students in the first year of college and if it occurs for too long, it will cause negative impact, therefore social support is needed. Social support refers to comfort feeling that occurs through social process that can make a person reduce the negative impact caused by negative stress. This study aims to find out about relationship between social support and homesickness in first year students that came from outside Java Island at Widya Mandala Catholic University Surabaya Pakuwon City Campus. Participant in this research $(N=149)$ is the first year students that came from outside Java Island at Widya Mandala Catholic University Surabaya Pakuwon City Campus. Sampling technique that used in this study was disproportionate stratified random sampling. This study was analyzed using non parametric correlated method Kendall's Tau-b. Result of this study shows correlation coefficient $(r)=-0,381$ dan $p=0,000(p<0,05)$, it means there is significant negative correlations between social support and homesickness in first year students that came from outside Java Island at Widya Mandala Catholic University Surabaya Pakuwon City Campus.

Keywords: Homesickness, Social Support, First Year Students 


\section{PENDAHULUAN}

Pendidikan merupakan hal yang penting untuk setiap individu. Pendidikan merupakan hal yang penting karena dapat meningkatkan kualitas sumber daya manusia dan juga bermanfaat untuk bekal di masa depan. Banyak dari masyarakat yang seringkali menempuh pendidikan jauh dari tempat tinggal mereka bahkan sampai ke luar negeri untuk menuntut ilmu setinggi mungkin. Indonesia sendiri memiliki banyak lembaga akademik yang bertujuan untuk meningkatkan kecerdasan masyarakat agar masyarakat mendapatkan pendidikan yang layak. Data BPS (Badan Pusat Statistik, 2017) menunjukkan bahwa terdapat 3.225 perguruan tinggi yang tersebar di seluruh Indonesia.

Berdasarkan data Ristekdikti (Kementrian Riset Teknologi dan Pendidikan Tinggi Indonesia, 2016) dari total 5.153.971 mahasiswa yang tersebar di seluruh Indonesia, Pulau Jawa menempati urutan pertama dengan total mahasiswa terbanyak yaitu sejumlah 721.652 mahasiswa. Data tersebut menunjukkan bahwa dari berbagai provinsi yang tersebar di Indonesia, jumlah mahasiswa terbanyak ada di pulau Jawa. Data tersebut juga menunjukkan bahwa pulau Jawa memang menjadi tujuan para calon mahasiswa baru.

Mahasiswa baru merupakan individu yang memasuki tahap perkembangan remaja akhir menuju dewasa awal. Di masa ini umumnya seseorang lebih aktif berpartisipasi di lingkungan dibandingkan dengan tahap perkembangan sebelumnya. Transisi dari masa remaja akhir menuju dewasa awal disebut dengan masa emerging adulthood. Menurut Arnett (2012: 10), ketika individu memasuki masa transisi dari SMA ke perkuliahan, maka individu tersebut dapat dikatakan memasuki masa emerging adulthood dengan rentang usia dari 18-25 tahun. Mereka yang memasuki masa emerging adulthood (dalam Santrock, 2014: 422) memiliki karakteristik seperti suka bereksperimen, mencari identitas diri yang sebenarnya, dan mengikuti gaya hidup yang mereka inginkan. Masa emerging adulthood merupakan masa dimana individu memiliki kesempatan untuk membuat perubahan dalam hidupnya.

Karakteristik yang paling menonjol pada tahap perkembangan emerging adulthood adalah eksplorasi. Masa ini merupakan usia dimana seseorang mengeksplorasi berbagai kemungkinan yang ada dalam hidupnya seperti cinta, pendidikan, dan pekerjaan. Selain itu, memilih pendidikan yang jauh dari tempat tinggal merupakan salah satu kemungkinan yang dipilih oleh individu. Menurut Rosenberg (2007), masa emerging adulthood merupakan masa dimana individu membangun kehidupan yang lebih mandiri dibandingkan masa perkembangan sebelumnya, termasuk didalamnya mandiri dalam membuat keputusan di area pendidikan (dalam Arnett, 2013: 11).

Ketika individu memilih untuk melanjutkan pendidikan di lingkungan lain yang jauh dari tempat tinggalnya, individu tersebut berhadapan dengan berbagai kemungkinan yang mungkin dialami di tempat baru. Salah satu hal yang umum dihadapi mahasiswa adalah homesickness. Menurut Thurber \& Walton (2007: 844) homesickness merupakan suatu keadaan distress yang disebabkan karena individu berpisah dari tempat tinggalnya. Homesickness ditandai dengan kognisi kuat tentang rumah dan hal-hal yang berkaitan dengan kelekatan terhadap objek tertentu. Menurut Van Tillburg (dalam Tillburg \& Vingerhoets, 2005: 35), homesickness merupakan sebuah emosi yang dirasakan oleh seseorang setelah meninggalkan rumah yang ditandai dengan emosi negatif, kognisi tentang rumah dan gejala somatik. 
Menurut Furnham (dalam Tillburg \& Vingerhoets, 2005: 20) homesickness muncul sebagai pemikiran yang kuat tentang rumah, perasaan untuk selalu ingin pulang ke rumah, kesedihan yang mendalam untuk rumah, dan adanya perasaan tidak nyaman yang dimiliki saat berada di tempat yang baru. Berdasarkan beberapa pengertian mengenai homesickness tersebut, dapat disimpulkan bahwa homesickness merupakan suatu distress atau perasaan tidak nyaman yang dapat terjadi karena individu berpisah dari lingkungan tempat tinggalnya serta ditandai dengan emosi negatif, dialaminya pemikiran yang kuat tentang rumah serta gejala somatik. Menurut Thurber dan Walton (2007), individu yang memiliki kemungkinan besar mengalami homesickness adalah mereka yang baru memulai perkuliahan, khususnya pada tahun pertama perkuliahan.

Transisi dari sekolah menengah atas menuju perguruan tinggi atau lingkup perkuliahan membawa banyak perubahan. Contoh perubahan yang dapat terjadi adalah individu mengalami lebih banyak interaksi dengan teman sebaya yang memiliki latar belakang yang berbeda-beda. Selain itu, individu memiliki kemungkinan mengalami tambahan tekanan untuk mencapai prestasi di bidang akademik maupun non-akademik (Santrock, 2014: 346). Transisi ini seringkali dianggap sebagai suatu tekanan terutama untuk mahasiswa rantau. Hal ini disebabkan karena mahasiswa rantau seringkali dihadapkan pada suatu perubahan lingkungan yang mengharuskan individu melakukan proses penyesuaian diri di lingkungan yang baru. Perubahan tersebut meliputi, perpisahan dengan orang tua, tuntutan hidup mandiri, serta menyesuaikan diri dengan teman-teman baru yang berasal dari latar belakang yang berbeda-beda. Jika individu tidak dapat menyesuaikan diri dengan baik dan belum terbiasa dengan lingkungan yang baru, perubahan tersebutlah yang seringkali mengakibatkan homesickness.

Sebagai mahasiswa khususnya mahasiswa perantau, sudah semestinya bertanggung jawab atas pilihan yang mereka ambil, salah satunya adalah pilihan untuk menuntut ilmu jauh dari lingkungan tempat tinggal. Menurut Charles \& Luong (2011), individu yang masuk dalam tahap perkembangan emerging adulthood (transisi dari remaja ke dewasa awal) akan mengurangi perasaan yang tidak stabil, lebih bertanggung jawab dan mengurangi perilaku yang sifatnya beresiko (dalam Santrock, 2012: 452). Mahasiswa rantau seharusnya memiliki kemandirian untuk menyesuaikan diri di tempat asing karena mereka sudah memasuki tahap remaja akhir menuju dewasa awal dan bisa dikatakan sudah cukup dewasa sehingga tidak terlalu rentan mengalami homesickness. Hal ini didukung oleh pernyataan menurut Baier dan Welch (1992) yang menyatakan bahwa, homesickness lebih rentan terjadi pada anak - anak dibandingkan dengan orang dewasa (dalam Tillburg \& Vingerhoets, 2005: 41). Menurut Santrock (2012: 16), usia yang dapat dikategorikan sebagai anak-anak adalah usia 3 tahun sampai 11 tahun.

Senyatanya masih ditemukan mahasiswa yang mengalami homesickness dikarenakan permasalahan seperti proses penyesuaian diri, dukungan sosial yang kurang serta tugas yang berat. Homesickness yang dialami individu bahkan dapat berdampak pada dialaminya penyesalan mengambil pendidikan yang jauh dari tempat tinggal. Hal tersebut mencirikan bahwa individu kurang bertanggung jawab dengan pilihan yang ia ambil. Pernyataan tersebut didukung dengan data wawancara preliminary yang dilakukan terhadap salah satu mahasiswa rantau angkatan 2015 di Universitas Katolik Widya Mandala Surabaya Kampus Pakuwon City yang menyatakan bahwa ia mengalami homesickness di tahun pertama perkuliahan.

Berdasarkan data wawancara preliminary dengan informan, informan juga menyatakan bahwa salah satu faktor yang menyebabkan ia mengalami homesickness adalah rasa kesepian yang ia alami saat berada di kos. Berdasarkan pernyataan tersebut 
diketahui bahwa informan membutuhkan kehadiran seseorang yang dapat membuat rasa kesepiannya berkurang, salah satunya dengan adanya dukungan sosial. Hasil penelitian terhadap mahasiswa yang dilakukan oleh Thurber \& Walton (2012) menyatakan bahwa mahasiswa yang memiliki teman baik untuk mencurahkan isi hatinya cenderung tidak terlalu merasakan homesickness. Hasil dari penelitian tersebut juga menyatakan adanya keterkaitan antara dukungan sosial dengan homesickness yang dialami oleh mahasiswa.

Dukungan sosial merupakan perasaan nyaman, diperhatikan, serta perasaan terbantu yang berasal dari seseorang atau kelompok kepada individu (Sarafino \& Smith, 2011: 81). Dukungan sosial dapat datang dari berbagai sumber, misalnya keluarga, teman, kekasih, dari suatu organisasi ataupun kelompok. Menurut Goldsmith (2004: 1) dukungan sosial merupakan sebuah harapan dalam hubungan individu yang ditandai dengan kepuasan bersama teman, keluarga, dan pasangan. Selain itu menurut Cohen, Gottlieb \& Underwood (2000: 4), dukungan sosial merupakan suatu proses yang terjadi melalui hubungan sosial yang dapat meningkatkan kesehatan dan kesejahteraan. Berdasarkan pendapat para ahli mengenai dukungan sosial, dapat disimpulkan bahwa dukungan sosial merupakan suatu perasaan nyaman ataupun terbantu yang didapatkan oleh seseorang dari berbagai sumber yang dapat meningkatkan kesehatan dan kesejahteraan.

Penelitian ini bertujuan untuk mengetahui hubungan antara dukungan sosial dan homesickness pada mahasiswa rantau semester satu yang berasal dari luar Pulau Jawa yang menempuh pendidikan di Universitas Katolik Widya Mandala Surabaya Kampus Pakuwon City. Hal yang membedakan penelitian ini dengan penelitian lainnya adalah peneliti ingin melihat hubungan kedua variabel tersebut di Indonesia, karena pada beberapa penelitian sebelumnya hanya memfokuskan pada variabel homesickness saja dan kebanyakan penelitian dilakukan di luar negeri. Adapun penelitian yang dilakukan di Indonesia tidak sebanyak dengan penelitian yang dilakukan di luar negeri. Hipotesa dari penelitian ini adalah "ada hubungan antara dukungan sosial dan homesickness pada mahasiswa rantau semester satu yang berasal dari luar Pulau Jawa di Universitas Katolik Widya Mandala Surabaya Kampus Pakuwon City”.

\section{METODE PENELITIAN}

Variabel penelitian yang digunakan dalam penelitian ini adalah variabel tergantung yaitu homesickness dan variabel bebas yaitu dukungan sosial. Populasi yang diambil dalam penelitian ini adalah mahasiswa Universitas Katolik Widya Mandala Surabaya Kampus Pakuwon City yang berasal dari luar Pulau Jawa yang merupakan angkatan 2018. Populasi ini digunakan karena menurut Thurber \& Walton (2012), individu yang memiliki kemungkinan besar untuk mengalami homesickness adalah mereka yang baru memulai perkuliahan khususnya pada tahun pertama perkuliahan. Teknik pengambilan sampel dalam penelitian ini adalah dengan menggunakan teknik disproportionate stratified random sampling, yaitu teknik pengambilan sampel yang digunakan jika populasi berstrata namun kurang proporsional (Sugiyono, 2011: 83). Sampel tersebut diambil dari setiap fakultas di Universitas Katolik Widya Mandala Surabaya Kampus Pakuwon City (berstrata) dengan jumlah mahasiswa yang diambil berbeda di setiap fakultasnya (kurang proporsional) dikarenakan jumlah mahasiswa dari setiap fakultas berbeda-beda. Mahasiswa yang akan diambil adalah mahasiswa angkatan 2018 di Universitas Katolik Widya Mandala Surabaya Kampus Pakuwon City. Alasan pengambilan populasi dan sampel dikarenakan data yang didapatkan dari BAAK (Biro 
Administrasi Akademik dan Kemahasiswaan, 2018) menunjukkan bahwa mahasiswa yang berasal dari luar Pulau Jawa paling banyak terdapat di Kampus Pakuwon City Surabaya yaitu, Fakultas Farmasi. Penentuan jumlah sampel yang akan digunakan menggunakan perhitungan rumus slovin (Kriyantono, 2008:162), yaitu

$$
\mathrm{n}=\frac{\mathrm{N}}{1+\mathrm{Ne}^{2}}
$$

Keterangan:

$\mathrm{n}=$ jumlah sampel

$\mathrm{N}=$ jumlah populasi

$\mathrm{e}=$ kelonggaran ketidaktelitian karena kesalahan pengambilan sampel yang dapat ditolerir kemudian dikuadratkan.

Sedangkan, penentuan jumlah sampel berdasarkan strata yang ada menggunakan rumus (Prasetyo \& Jannah, 2012: 130) sebagai berikut:

$$
\text { Sampel }=\frac{\text { Populasi }}{\text { Total Populasi }} \times \text { Total Sampel }
$$

Berdasarkan hasil penelitian ini partisipan terbanyak yang diambil dalam penelitian ini berasal dari Fakultas Farmasi yaitu 96 mahasiswa, menyusul kemudian Fakultas Psikologi dan Kedokteran dengan 19 mahasiswa, Fakultas Keperawatan dengan 14 mahasiswa dan terakhir berasal dari Fakultas Filsafat yaitu 1 mahasiswa. Berdasarkan jenis kelaminnya, partisipan terbanyak merupakan mahasiswa dengan jenis kelamin perempuan yaitu 122 mahasiswa, sedangkan mahasiswa dengan jenis kelamin laki-laki berjumlah 27, sedangkan jika dilihat dari usianya partisipan terbanyak merupakan mahasiswa dengan usia 18 tahun sebanyak 94 mahasiswa, menyusul kemudian usia 17 tahun sebanyak 31 mahasiswa, dan usia 19 tahun sebanyak 15 mahasiswa.

\section{Alat Ukur}

Alat ukur dalam penelitian ini dibuat sendiri oleh peneliti dengan jumlah aitem untuk variabel homesickness sebanyak 20 aitem yang terdiri dari 4 aspek, yaitu aspek situasi antecenden, aspek individu, aspek reaksi, serta aspek regulasi sosial dan kontrol. Berikutnya jumlah aitem variabel dukungan sosial sebanyak 16 aitem yang terdiri dari 4 aspek, yaitu aspek dukungan emosional, aspek dukungan instrumental, aspek dukungan informasional, dan aspek dukungan companionship. Skala yang digunakan dalam alat ukur ini adalah skala likert yang terdiri dari aitem favorable dan unfavorable dengan 5 pilihan jawaban, yaitu sangat setuju (SS), setuju (S), netral (N), tidak setuju (TS), dan sangat tidak setuju (STS). Pada aitem favorable akan diberikan bobot nilai 5 untuk SS, 4 untuk S, 3 untuk N, 2 untuk TS, dan 1 untuk STS begitu juga sebaliknya untuk aitem unfavorable.

Validitas yang digunakan dalam penelitian ini adalah validitas isi. Validitas isi adalah sejauh mana kesesuaian (relevansi) aitem-aitem dalam dengan indikator perilaku 
dan atribut yang diukur (Azwar, 2015: 175). Penelitian ini juga menggunakan validitas aitem dengan menggunakan proses perhitungan statistik daya diskriminasi aitem yang dapat menentukan apakah aitem dapat dikatakan valid atau tidak. Aitem dapat dikatakan valid apabila nilai corrected item total correlation $\geq 0,30$ (Azwar, 2015: 86). Pengukuran reliabilitas pada penelitian ini menggunakan nilai dari Alpha Cronbach, yaitu reliabilitas dari alat ukur dianggap baik apabila nilai koefisiennya berada diantara 0 hingga 1,00. Semakin tinggi koefisien reliabilitasnya sampai mendekati 1,00 menyatakan bahwa semakin tinggi pula reliabilitasnya. Sebaliknya, semakin koefisien reliabilitasnya mendekati angka 0 , menyatakan bahwa reliabilitasnya semakin rendah. Senyatanya dalam pengukuran psikologi koefisien 1,00 tidak pernah dijumpai (Azwar, 2015: 181) sehingga nilai Alpha Cronbach minimum yang dapat diterima adalah 0,70 (Pallant, 2007: 6). Seluruh pengujian akan menggunakan bantuan program SPSS 16.0 for windows.

\section{Teknik Analisis Data}

Teknik analisis data yang digunakan dalam penelitian ini adalah teknik korelasi Pearson Product Moment, namun sebelum itu terlebih dahulu dilakukan uji asumsi berikut:

a. Uji Normalitas adalah analisis data yang digunakan untuk mengetahui apakah data yang diperoleh telah mengikuti distribusi frekuensi kurva normal atau tidak. Data dikatakan berdistribusi normal jika nilai signifikasinya $(p) \geq 0,05$.

b. Uji Linearitas adalah pengujian yang dilakukan untuk mengetahui apakah hubungan atau korelasi antara variabel tergantung dan variabel bebas berada dalam suatu garis lurus (linear). Hubungan dapat dikatakan linear apabila nilai $p$ $\leq 0,05$.

Jika uji asumsi diatas terpenuhi, maka selanjutnya dapat dilakukan teknik statistik parametrik yaitu korelasi Pearson Product Moment. Teknik ini digunakan untuk mengetahui ada atau tidaknya hubungan antara variabel tergantung dengan variabel bebas. Apabila salah satu uji asumsi diatas tidak terpenuhi, maka akan dilakukan teknik statistik non-parametrik yaitu Kendall's Tau-b. Menurut Howell (dalam Field, 2013: 352) Kendall's Tau-b merupakan uji statistik non parametrik yang disarankan untuk digunakan karena lebih baik untuk menguji hubungan dalam suatu populasi, selain itu juga lebih akurat dalam menggeneralisasikan data.

\section{HASIL PENELITIAN}

Setelah dilakukan pengolahan data, maka didapatkan hasil sebagai berikut:

\section{Hasil Uji Validitas}

Berdasarkan hasil uji validitas menggunakan program SPSS 16.0 for windows, diperoleh hasil uji validitas untuk variabel homesickness dan dukungan sosial dilihat berdasarkan kolom corrected item-total correlation. Pada variabel homesickness masing-masing aitem sahih dan gugur berjumlah 17 dan 3 aitem. Pada variabel dukungan sosial masing-masing aitem sahih dan gugur berjumlah 13 dan 3 aitem. Pada masing-masing alat ukur tersebut aitem dapat dikatakan valid apabila nilai corrected item total correlation $\geq 0,30$ (Azwar, 2015: 86). 


\section{Hasil Uji Reliabilitas}

Uji reliabilitas pada penelitian ini menggunakan teknik komputasi formula alpha cronbach. Pengukuran reliabilitas pada penelitian ini menggunakan nilai dari Alpha Cronbach, yaitu reliabilitas dari alat ukur dianggap baik apabila nilai koefisiennya berada diantara 0 hingga 1,00. Berdasarkan hasil uji reliabilitas menggunakan program SPSS 16.0 for windows didapatkan reliabilitas skala homesickness 0,862 (berada diatas 0,7), sehingga bisa disimpulkan bahwa skala homesickness reliabel. Kemudian untuk skala dukungan sosial didapatkan reliabilitas 0,881 (berada diatas 0,7 ), sehingga skala juga dikatakan reliabel.

\section{Hasil Uji Asumsi}

Tahap selanjutnya dalam penelitian ini adalah melakukan uji asumsi. Penelitian ini bertujuan untuk menguji adanya hubungan antara variabel homesickness dan dukungan sosial, oleh karena itu menggunakan uji hubungan product moment correlation. Sebelum melakukan uji hubungan, maka diperlukan uji asumsi yaitu uji normalitas dan uji linearitas. Berikut merupakan hasil uji asumsi menggunakan program SPSS 16.0 for windows:

a. Uji Normalitas

Berdasarkan kolom kolmogorov-smirnov, diperoleh sig. 0,200 $(p>0,05)$ dan nilai statistik sebesar 0,053 untuk variabel homesickness, sehingga dapat disimpulkan bahwa variabel homesickness terdistribusi normal. Kemudian, untuk variabel dukungan sosial diperoleh sig. 0,043 $(p<0,05)$ dan nilai statistik sebesar 0,074 , sehingga dapat disimpulkan bahwa variabel dukungan sosial tidak memenuhi uji normalitas. Hal ini menyebabkan statistik yang digunakan adalah statistik non-parametrik yaitu Kendall's Tau- $b$.

b. Uji Linearitas

Berdasarkan kolom linearity diperoleh sig. 0,000 $(p<0,05)$ dan nilai deviation from linearity sebesar 0,528 , sehingga dapat dinyatakan memenuhi uji linearitas.

\section{Hasil Uji Hipotesis}

Berdasarkan hasil uji asumsi diatas, dapat disimpulkan bahwa uji normalitas tidak terpenuhi sedangkan uji linearitas terpenuhi. Dikarenakan tidak memenuhi salah satu uji asumsi maka digunakan statistik non-parametrik yaitu Kendall's Tau-b. Berdasarkan uji tersebut, diperoleh sig. 0,000 $(p<0,05)$ serta nilai koefisien korelasi antara homesickness dan dukungan sosial sebesar -0,381, sehingga dapat disimpulkan bahwa ada hubungan antara dukungan sosial dan homesickness pada mahasiswa rantau semester satu yang berasal dari luar Pulau Jawa di Universitas Katolik Widya Mandala Pakuwon City Surabaya. Adapun nilai correlation coefficient sebesar -0,381 yang berarti hubungan negatif. Hal tersebut menandakan bahwa semakin tinggi dukungan sosial maka semakin rendah homesickness begitu juga sebaliknya. Selain itu, berdasarkan nilai koefisien determinasi ( $R$ square) menunjukkan bahwa variabel 
dukungan sosial memberikan sumbangan sebesar $34,2 \%$ terhadap variabel homesickness, sementara sisanya disebabkan oleh faktor-faktor lain.

\section{DISKUSI}

Berdasarkan hasil uji hipotesis statistik non-parametrik menggunakan metode Kendall's Tau $b$, diperoleh sig. 0,00 $(p<0,05)$ yang menandakan Ho gagal diterima. Hal tersebut menyatakan bahwa penelitian ini sejalan dengan hipotesis yang diajukan yaitu ada hubungan antara dukungan sosial dan homesickness pada mahasiswa rantau semester satu yang berasal dari luar Pulau Jawa di Universitas Katolik Widya Mandala Pakuwon City Surabaya. Selain itu diperoleh pula nilai correlation coefficient sebesar 0,381 yang berarti hubungan negatif atau berbanding terbalik. Hal ini berarti bahwa semakin tinggi dukungan sosial yang diberikan maka semakin rendah homesickness yang dimiliki, begitu juga sebaliknya.

Hasil penelitian ini juga didukung oleh penelitian sebelumnya yang dilakukan oleh Harijanto dan Setiawan (2017) yang menjelaskan adanya hubungan antara dukungan sosial, homesickness dan kebahagiaan pada mahasiswa perantau di Surabaya. Dalam penelitian tersebut dinyatakan bahwa homesickness merupakan salah satu faktor ketidakbahagiaan yang dirasakan oleh mahasiswa rantau. Oleh sebab itu, untuk mengubah ketidakbahagiaan yang dialami mahasiswa rantau menjadi kebahagiaan, dibutuhkan dukungan sosial dari orang di sekitarnya.

Penelitian terkait yang mendukung penelitian ini juga dilakukan oleh Pardede (2015) yang menyatakan adanya hubungan berbanding terbalik antara homesickness dengan kedekatan sosial. Penelitian tersebut menjelaskan bahwa homesickness yang dialami mahasiswa dari berbagai universitas di Amerika dapat meningkat akibat kurangnya interaksi atau hubungan dengan teman sebayanya. Penelitian lainnya yang mendukung juga dilakukan di salah satu Universitas di Sumatera (Rufaida \& Kustanti, 2017). Pada penelitian tersebut disebutkan bahwa terdapat hubungan antara dukungan sosial dengan penyesuaian diri mahasiswa rantau. Penelitian tersebut mendukung penelitian ini karena berdasarkan taksonomi APA (American Psychiatric Association), homesickness diklasifikasikan dalam gangguan penyesuaian diri (Thurber \& Walton, 2007: 843).

Berdasarkan tabel kategorisasi (tabel 4.4.) menunjukkan bahwa dalam penelitian ini mahasiswa umumnya memiliki homesickness dengan kategori rendah yaitu, 87 mahasiswa, sedangkan untuk dukungan sosial (tabel 4.5.) pada umumnya berada pada kategori tinggi sebanyak 75 mahasiswa. Selanjutnya pada tabel tabulasi silang (tabel 4.6.) dapat dilihat bahwa umumnya mahasiswa berada dalam kategori homesickness rendah dengan kategori dukungan sosial yang tinggi karena memiliki frekuensi terbanyak yaitu 54 mahasiswa dari 149 mahasiswa. Kemudian menyusul mahasiswa dalam kategori homesickness rendah dan kategori dukungan sosial sangat tinggi sebanyak 30 mahasiswa. Sebaliknya mahasiswa yang berada dalam kategori homesickness tinggi dan dukungan sosial rendah hanya 1 mahasiswa dari total 149 mahasiswa, selain itu tidak ada mahasiswa yang berada dalam kategori homesickness sangat tinggi dengan dukungan sosial sangat rendah. Kategori ini ditentukan melalui perhitungan kategorisasi nilai mean dan sd ideal. 
Dilihat berdasarkan tabel-tabel tersebut dapat disimpulkan bahwa mayoritas mahasiswa Universitas Katolik Widya Mandala Pakuwon City Surabaya angkatan 2018 yang berasal dari Luar Pulau Jawa memiliki homesickness yang tergolong rendah dan dukungan sosial yang tergolong tinggi. Selain itu, berdasarkan nilai koefisien determinasi ( $R$ square) menunjukkan bahwa variabel dukungan sosial memberikan sumbangan sebesar $34,2 \%$ terhadap variabel homesickness, sementara sisanya disebabkan oleh faktor-faktor lain. Hal ini didukung pula oleh penelitian kualitatif yang dilakukan di Universitas Midwestern Amerika Serikat yang menyatakan bahwa individu yang mengalami homesickness membutuhkan dukungan sosial baik secara langsung maupun tidak langsung (Scharp, Paxman \& Thomas, 2017).

Faktor lain yang menyebabkan homesickness diantaranya adalah faktor pengalaman, faktor kepribadian, faktor keluarga, maupun faktor sikap (Thurber \& Walton, 2007: 846). Faktor kepribadian dalam hal ini lebih difokuskan kepada kepribadian yang dapat terbentuk akibat pola asuh yang diberikan saat masa kanakkanak. Dijelaskan bahwa insecure attachment yang diberikan oleh pengasuh kepada anak dapat membuatnya lebih rentan mengalami homesickness (dalam Tillburg \& Vingerhoets, 2005: 42). Pola asuh tersebutlah yang pada akhirnya dapat membentuk kepribadian seseorang yang takut berpisah dari sosok yang dianggapnya sebagai pengasuh, dalam hal ini bisa orang tua ataupun caregiver-nya.

Berdasarkan data-data yang telah didapat memperkuat hipotesis dari penelitian ini bahwa ada hubungan antara dukungan sosial dan homesickness pada mahasiswa semester satu UKWMS Pakuwon City yang berasal dari luar Pulau Jawa. Adapun hubungan dalam penelitian ini sifatnya negatif dengan nilai correlation coefficient sebesar -0,381. Nilai tersebut menandakan bahwa semakin tinggi dukungan sosial seseorang maka semakin rendah homesickness yang dimiliki begitu juga sebaliknya.

Selanjutnya jika dilihat berdasarkan data deskriptif frekuensi berdasarkan jenis kelamin (tabel 4.2.) didapatkan bahwa dalam penelitian ini, yang lebih banyak menjawab kuesioner adalah jenis kelamin perempuan dibandingkan dengan laki-laki. Hal tersebut dibuktikan dari distribusi frekuensi perempuan sebanyak 122 orang sedangkan laki-laki sebanyak 27 orang. Fisher (dalam Tillburg \& Vingerhoets 2005: 42) tidak menemukan adanya perbedaan gender dalam hal homesickness, yang berarti siapa saja dapat mengalaminya tanpa terkecuali.

Adapun beberapa keterbatasan dalam pelaksanaan penelitian ini yaitu:

a. Peneliti menggunakan google form dalam penyebaran kuesioner

Hal ini menyebabkan peneliti tidak bisa melakukan pendekatan secara langsung kepada partisipan (hanya sebatas melalui chat). Selain itu, ada beberapa partisipan yang sulit dihubungi sehingga pengisian kuesioner sedikit mengalami hambatan.

b. Faktor-faktor diluar kontrol peneliti

Faktor lain yang dimaksud yaitu kondisi dan respon dari partisipan, seperti faktor kejenuhan yang mungkin menyebabkan partisipan sekedar mengisi kuesioner sehingga bukan merupakan kondisi sebenarnya. Selain itu, 
dikarenakan pembagian kuesioner diijinkan diluar mata kuliah sehingga terkadang ada beberapa partisipan yang lupa untuk mengembalikan kuesioner.

\section{KESIMPULAN DAN SARAN}

\section{Simpulan}

Berdasarkan data-data dan pembahasan dapat disimpulkan bahwa ada hubungan negatif antara homesickness dan dukungan sosial. Adanya hubungan didapatkan berdasarkan hasil uji hipotesis non-parametrik yang menunjukkan nilai signifikansi sebesar $0,000(p<0,05)$ dengan nilai correlation coefficient sebesar $-0,381$, yang menunjukkan bahwa semakin tinggi dukungan sosial yang diperoleh maka semakin rendah homesickness seseorang. Hal tersebut juga dibuktikan berdasarkan nilai koefisien determinasi ( $R$ square) menunjukkan bahwa variabel dukungan sosial memberikan sumbangan sebesar 34,2\% terhadap variabel homesickness.

\section{Saran}

Adapun beberapa saran yang diberikan peneliti terkait keterbatasan dan hasil penelitian, yaitu:

a. Bagi peneliti selanjutnya diharapkan bisa memperhatikan keterbatasan penelitian ini, misalnya dalam penggunaan google form serta memperhatikan faktor lain seperti kejenuhan dari informan. Selain itu, peneliti selanjutnya juga diharapkan bisa mengkaitkan antara aspek kepribadian dengan homesickness

b. Bagi universitas, terkait dengan hasil penelitian yang menunjukkan masih terdapat mahasiswa yang memiliki kategori homesickness tinggi dengan dukungan sosial yang rendah, diharapkan dapat membantu mahasiswa rantau untuk mendapatkan dukungan sosial misalnya dengan membuat program yang banyak melibatkan interaksi dengan mahasiswa lain di lingkungan perkuliahan.

c. Bagi peneliti selanjutnya, diharapkan bisa memperhatikan keterbatasan penelitian ini, selain itu juga bisa mengkaitkan antara aspek kepribadian dengan homesickness.

\section{Referensi}

Arnett, J.J. (2012). Adolescence and Emerging Adulthood: A Cultural Approach (5 ${ }^{\text {th }}$ Edition). USA: Pearson Education, Inc

Azwar, S. (2013). Dasar-dasar Psikometri. Yogyakarta: Pustaka Pelajar

Azwar, S. (2015). Penyusunan skala psikologi (Edisi ke-2). Yogyakarta: Pustaka Pelajar

Azwar, S. (2015). Tes Prestasi: Fungsi dan Pengembangan Pengukuran Prestasi Belajar (Edisi ke 2). Yogyakarta: Pustaka Belajar

Badan Pusat Statistik Jawa Timur. (2015). Diakses dari https://www.bps.go.id/statictable/2015/09/14/1839/jumlah-perguruan-tinggimahasiswa-dan-tenaga-edukatif-negeri-dan-swasta-di-bawah-kementrianpendidikan-dan-kebudayaan-menurut-provinsi-2013-2014-2014-2015.html pada tanggal 20 Maret 2018 
Biasi, Valeria dkk. (2018). Homesickness Experience, Distress and Sleep Quality of First Year University Students Dealing with Academic Environment. Journal of Educational and Social Research, 8(1), 9-17

Cohen, S., Underwood, L.G., \& Gottlieb, B.H. (2000). Social Support Measurement and Intervention: A Guide for Health and Social Scientist. New York: Oxford University Press

Field, A. (2013). Discovering Statistics Using IBM SPSS Statistics (4 ${ }^{\text {th }}$ Edition). Canada: Transcontinental Printing Inc

Furnham, A. (2005). Culture Shock, Homesickness and Adaptation to a Foreign Culture. Dalam Tillburg \& Vingerhoets (Ed). Psychological Aspects of Geographical Moves: Homesickness and Acculturation Stress. (h. 17-32). Amsterdam: Amsterdam University Press

Goldsmith, D.J. (2004). Communicating Social Support. USA: Cambridge University Press

Harijanto, J. \& Setiawan, J.L. (2017). Hubungan antara Dukungan Sosial dan Kebahagiaan pada Mahasiswa Perantau di Surabaya. [Versi Elektronik]. Surabaya: Fakultas Psikologi Universitas Ciputra

Kamus Besar Bahasa Indonesia. (2018). [Online]. Diakses dari https://kbbi.kemdikbud.go.id/ pada tanggal 20 Maret 2018

Kementrian Riset, Teknologi, dan Pendidikan Tinggi. (2016). Laporan Tahunan. Diakses dari https://ristekdikti.go.id/wp-content/uploads/2017/07/BukuLaporan-Tahunan-2016.pdf pada tanggal 20 Maret 2018

Krisyanto, R. (2008). Teknik Praktis Riset Komunikasi: Disertai Contoh Praktis Riset Media, Public Relations, Advertising, Komunikasi Organisasi, Komunikasi Pemasaran (Edisi 1). Jakarta: Fajar Interpratama Offset

Pallant, J. (2007). SPSS Survival Manual: A Step by Step Guide to Data Analysis using SPSS Version 15 ( $3^{\text {th }}$ Edition). New York: McGraw Hill

Pardede, G.H. (2015). Homesickness Among International College Students: The Impact of Social Embeddedness and Connection to Home (Thesis). Texas: Baylor University

Prasetyo, B., \& Jannah, L. M. (2012). Metode penelitian kuantitatif: teori dan aplikasi. Jakarta: Rajawali Pers

Rufaida, H \& Kustanti, E.R. (2017). Hubungan antara Dukungan Sosial Teman Sebaya dengan Penyesuaian Diri pada Mahasiswa Rantau dari Sumatera di Universitas Diponegoro. Jurnal Empati, 3(7), 217-222.

Santrock, J.W. (2012). Life Span Development (14 ${ }^{\text {th }}$ Edition). New York: McGraw Hill Companies, Inc

Sarafino, E.P. \& Smith, T.W. (2010). Health Psychology: Biopsychosocial Interaction ( $7^{\text {th }}$ Edition). New Jersey: John Wiley \& Sons, Inc

Scharp, K.M., Paxman, C.G. \& Thomas, L.J. (2015). I Want to Go Home: Homesickness Experiences and Social Support Seeking Practices. Journal of Environment and Behavior, 1-23

Sugiyono. (2010). Statistika untuk Penelitian (Edisi ke 17). Bandung: CV. Alfabeta

Sugiyono. (2011). Metode Penelitian Kuantitatif Kualitatif dan $R \& D$. Bandung: Alfabeta

Thurber CA, Walton E. (2007). Preventing and Treating Homesickness. USA: Elsevier 
Thurber, C. A., \& Walton, E. A. (2012). Homesickness and Adjustment in University Students. Journal of American College Health, 60, 1-5

Tillburg, M \& Vingerhoets, A. (2005). Psychological Aspects of Geographical Moves:

Homesickness and Acculturation Stress. Amsterdam: Amsterdam University Press 